\title{
Mikołaj Ratajczak \\ Poza paradygmat immunizacji: \\ biopolityka w projekcie filozoficznym \\ Roberta Esposita
}

Celem tekstu jest rekonstrukcja wybranych wątków z twórczości Roberta Esposita, które w opinii autora budują rdzeń omawianej koncepcji filozoficznej.

Rekonstrukcja ta oscyluje wokół pojęć komunizacji, immunizacji, nowoczesności oraz biopolityki, a jej zadaniem jest uchwycenie wewnętrznego związku między tymi terminami. Elementem wiążącym komunizację i immunizację jest negatywność, która zarazem umożliwia wspólnotowe życie, jak i stanowi zagrożenie dla jej członków. Z racji faktu, że dialektyka między komunizacją i immunizacją dotyczy, na najbardziej radykalnym poziomie, relacji między życiem i śmiercią, problematyka wspólnoty okazuje się być nieodłączna od zagadnienia biopolityki.

Słowa kluczowe: Esposito - Foucault - Agamben - Nancy - Hobbes - Virchow - biopolityka - wspólnota - immunizacja - ciało nowoczesność - system immunologiczny. 


\section{Niczym \\ byliśmy, jesteśmy, \\ pozostaniemy, kwitnac: róża Niczego, róża Nikogo \\ Paul Celan}

A przecież wtaśnie w ciemnościach - i jako ciemność sama - ciato zostato poczęte, pojęte Jean-Luc Nancy

\section{Prolegomena: Immunizacja}

Wraz ze wzrostem w świecie zagrożeń dla żywego podmiotu - a także przy coraz barziej globalnym charakterze tych zagrożeń - wzrasta również potrzeba stworzenia dyskursów filozoficznych, które potrafiłyby zareagować na postępujący rozpad podmiotowości. Przy czym nie chodzi oczywiście o utrwalanie przekazanych przez tradycję granic i funkcji podmiotowości, lecz o walkę z procesami odzierania jej z jej władz - z depolityzacją, nihilizmem, alienacją doświadczenia, redukcją do bycia epifenomenem procesów wymiany towarów bądź informacji, z redukcją do nagiego życia.

Pojęciem, które od jakiegoś czasu zaczyna odgrywać istotną rolę w debatach filozoficznych eksplikujących kwestię zagrożenia dla życia podmiotowego i społecznego (oraz jego tworzenia), jest pojęcie immunizacji. Jego znaczenie i użyteczność polega na odnoszeniu się jednocześnie do dwóch istotowo różnych dyskursów. $\mathrm{Z}$ jednej strony mamy bowiem prawne pojęcie immunitetu, chroniące jednostkę przed społecznymi zobowiązaniami prawnymi. Z drugiej strony, immunizacja jest fundamentalnym procesem konstytucji biologicznego organizmu, oddzielającym go od jego środowiskowego zewnętrza. W obu jednak przypadkach, zarówno w dyskursie prawnym, jak i biologiczno-medycznym, immunizacja polega na ochronie podmiotu.

Nic dziwnego zatem, że pojęcie immunizacji zagościło we współczesnym dyskursie filozoficznym w okresie pojawienia się nowych, niespotykanych wcześniej zagrożeń nie tylko dla życia, lecz również dla elementarnej tożsamości podmiotowej, rozumianej tutaj jako wyznaczenie granic wnętrza i zewnętrza oraz kontrola kontaminacji między tymi dwiema sferami. Pod koniec lat osiemdziesiątych, czyli po prawie dekadzie trwania epidemii AIDS $^{1}$, Donna Haraway uczyniła zagadnienie immunizacji oraz systemu immunologicznego kluczem nowego paradygmatu biopolitycznego, związanego z techniczno-informatyczną transformacją cielesności ${ }^{2}$. Podkreślała ich ważkość dla filozoficznej refleksji nad podmiotem, jako że „system immunologiczny jest mapa wykreśloną w celu poprawnego i błędnego rozpoznania siebie oraz innego w dialektyce zachodniej biopolityki" ${ }^{3}$.

Po atakach na World Trade Center we września 2001 Jacques Derrida odwołał się, w rozmowie z Giovanną Borradori, do pojęcia immunizacji (a dokładniej autoimmunizacji), próbując zakreślić ramy dekonstrukcyjnej analizy procesów globalizacji i jej wpływu na aparaty państw narodowych ${ }^{4}$. Rok po wspomnianej tragedii, ale i rok przed wydaniem wywiadu z Derridą, ukazała się książka włoskiego filozofa młodszego pokolenia, Roberta Esposita, Immunitas: protezione e negazione della vita [Immunitas: ochrona i negacja życia] ${ }^{5}$, w której zagadnienie immunizacji staje się podstawowym problemem filozoficznym, dotyczącym nie tylko kwestii wyznaczenia granicy między ja i nie-ja, lecz także wszelkich podstawowych kategorii filozofii (politycznej): wnętrza i zewnętrza, publicznego i prywatnego, życia i śmierci, jednostkowego i społecznego, pozytywnego i negatywnego itd. ${ }^{6}$

Immunitas stanowi drugą część trylogii, na którą składają się również: wydana w roku 1998 książka Communitas: origine e destino della comunità [Communitas: źródto i przeznaczenie wspólnoty $]^{7}$ oraz Bios: biopolitica e filosofia [Bios: biopolityka i filozofia] z roku 2004. Komunizacja, immunizacja i biopolityka - te trzy pojęcia stanowią rdzeń projektu filozoficznego Esposita, którego oryginalność polega na połączeniu trzech istotnych problemów współczesnej refleksji filozoficzno-politycznej: wspólnoty, bezpieczeństwa i biopolityki, za pomoca jednego związku pojęciowego. Należy podkreślić, że w sercu analizowanej przez Esposita dialektyki komunizacji (doświadczenia wspólnoty) i immunizacji (indywidualizacji) znajduje się mechanizm, który jest swego rodzaju reinterpretacją jednego z fundamentalnych problemów nowoczesnej (a także wszelkiej „ponowoczesnej”, 
jeśli jest sens o takowej w ogóle mówić) filozofii. Chodzi mianowicie o związek między różnicą ja i nie-ja oraz kwestią negatywności, której próby dyskursywnego uchwycenia (od Hegla przez Lebensphilosophie, Heideggera, egzystencjalizm, psychoanalizę, po dekonstrukcję oraz, współcześnie, tzw. „myśl postsekularną”) prowadziły do formułowania pojęciowej relacji między życiem a śmiercią. Tym samym w obszar tej problematyki wkracza wymiar biopolityczny, który dotyczy przecież regulacji i normalizacji relacji między życiem (normą bądź normalizacją życia) oraz śmiercią (granicą życia). Prezentacji tego związku logicznego w ujęciu Esposita poświęcony jest niniejszy tekst.

\section{Communitas i negatywność wspólnoty}

W analizie pojęcia wspólnoty czy też doświadczenia komunizacji Esposito wychodzi od rozważań etymologicznych ${ }^{8}$. Zauważa mianowicie, że w większości języków romańskich to, co wspólne (commun, comun, kommun) przeciwstawione jest temu, co własne (proprio). Ten sam wymiar znaczeniowy charakteryzował także greckie koinos oraz gotyckie gemein (stąd niemieckie Gemeinde, Gemeinschaft itd.). Aby uchwycić jednak specyfikę łacińskiego communis, opozycję tego, co własne i tego, co wspólne, należy rozpatrzyć w sposób bardziej radykalny, źródłowo, tematyzując ontologiczny moment wzajemnego zakładania się i odnoszenia się do siebie tych dwóch sfer.

$\mathrm{Na}$ samym tylko poziomie językowym łacińskie terminy communis oraz immunis łączy wspólny rdzeń - munus. Oznaczał on dar, lecz dar innego rodzaju niż donum. Relacja między nimi była relacją "gatunku do rodzaju" ", jako że munus był specyficznym rodzajem daru jako takiego (donum). O ile ten drugi odnosił się po prostu do specyficznej relacji wymiany darów ${ }^{10}$, o tyle munus oznaczał ,jedynie ten dar, który się dawało, a nie ten, który się otrzymywało" ${ }^{11}$. Odnosił się zatem do wymiaru pewnego przymusu, którego doświadcza się w relacji z innym. Przy czym właśnie z tego względu relacja ta wzbogacona zostaje o wymiar odpowiedzial- ności, nabierając tym samym charakteru wspólnotowego. Dlatego też communitas, czyli dzielenie tego samego munus, przymusu wyświadczania innym usług i wymiaru zobowiązań wobec nich, łączono w łacinie nie tylko $\mathrm{z}$ donum, lecz również z onus (obowiązek, przymus) oraz officium, publicznym urzędem. Urząd, stanowisko, funkcja publiczna były zatem nie tyle przywilejem, co wspólnotowym obowiązkiem wobec innych.

Urząd, stanowisko, przestrzeń publiczna - specyfika munus, który decydował o publicznym charakterze spraw polityki, w opozycji do prywatnej przestrzeni domostwa, każe nam zadać pytanie o grecką opozycję między polis a oikos. Wspólnota wymyka się bowiem owemu dualizmowi publiczne/prywatne: koinonia nie daje się zredukować do przestrzeni polis, tak samo jak communitas nie jest tym samym, co res publica. Specyfika wspólnotowego bycia, którą najlepiej wyraża munus w jego całkowicie tranzytywnym wymiarze, pozwala jednak na krytykę ontologicznego statusu owej res publica (rzeczypospolitej). Munus jako dar, którego nie można nie dać ${ }^{12}$, odnosi się do tego, co niemożliwe do przywłaszczenia, co nie może nigdy zostać przyswojone przez podmiot, tak indywidualny, jak i społeczny ${ }^{13}$. Tym samym wspólnota nie może być nigdy pojmowana jako podmiot określonej charakterystyki czy też jako poszerzony podmiot indywidualny. „Wspólnocie nie przynależy bycie na sposób rzeczy." ${ }^{14}$ Nie dzielimy żadnej wspólnej istoty, ani też nie istnieje jakakolwiek substancja wspólnotowego bycia; jako wspólnota nie posiadamy niczego wspólnie (a przynajmniej nie w nowoczesnym sensie posiadania), nic nas nie łączy. Ontologicznie rzecz biorąc, nie mamy nic wspólnego; a raczej to właśnie owo nic jest tym, co podzielamy jako byty wspólnotowe. 
Munus bowiem nie znaczy „jesteś mi coś winny”, lecz raczej „jestem ci coś winny” i w ten sposób odnosi się do wywłaszczającego (dosłownie: odbierającego to, co własne) charakteru bycia we wspólnocie. Nie jest to więc wymiar intersubiektywności, gdyż owo „inter”, którym jest wspólnotowy munus uniemożliwia mówienie o jakimkolwiek „subiectum”. Członkowie i członkinie wspólnoty odnajdują w niej bowiem jedynie „ową pustkę, ów dystans, zewnętrzność, która konstytuuje ich bycie poza nimi samymi" ${ }^{15}$; w tym sensie przestrzeń wspólnoty jest przestrzenią pierwotnego wywłaszczenia, uniemożliwiającego podmiotom utożsamienie się z jakąkolwiek cechą czy też własnością. Wspólnota nie jest więc także czymś utraconym ani też jakimś projektem, który można by zrealizować w przyszłości wspólnym wysiłkiem. Konieczność wspólnotowego dawania skazuje podmioty na dzielenie się nicością. Res communis okazuje się wywłaszczającą negatywnością, która umożliwia wspólnotowe życie - różą niczyją, którą można jedynie dać.

Ten ontologicznie negatywny wymiar wspólnoty wpisuje rozważania Esposita nad wzajemnym munus (będącym czymś całkowicie różnym od wzajemnego uznania) w dyskurs traktujący wspólnotę jako pojęcie wymykające się siatce terminów nowoczesnej filozofii (politycznej). Stanowi tym samym szansę zbudowania nowego dyskursu poza ograniczeniami klasycznych podziałów na liberalizm i socjalizm czy też indywidualizm i etatyzm itd. Tak samo jak Nancy ${ }^{16}$, Agamben ${ }^{17}$ czy Derrida ${ }^{18}$, również Esposito buduje swoją myśl polityczną w opozycji do klasycznej ontologii, w której to, co negatywne bądź oznaczało niebyt, bądź też (jak u Hegla) podporządkowane zostało bytowi (a byt jemu) w dialektycznym zapośredniczeniu. Nie zmienia to jednak faktu, że wymiar negatywności stanowi dla podmiotu zagrożenie. Skazuje go na dekonstrukcję (destrukcję), wywłaszczenie, na konfrontację z negatywnością, która w skrajnej postaci oznacza nic innego, jak śmierć. Doświadczenie wspólnoty związane jest z ekspozycją podmiotu, z naruszeniem granic oddzielających wnętrze od zewnętrza. Sama negatywność communitas, jeśli nie będą jej towarzyszyć mechanizmy chroniące podmiot, oznacza niekontrolowane niebezpieczeństwo śmierci.
Chcąc krótko podsumować ten etap rozważań Esposita, moglibyśmy powiedzieć, że akt komunikacji i nawiązywania relacji z innym jest zawsze niebezpieczny. Czy to jeśli chodzi o fizyczny kontakt biologicznych ciał, o komunikację między komputerami w sieci, czy też o międzynarodowe umowy i układy (a są to jedne z przykładów, do których odwołuje się sam Esposito, nie ograniczając się bynajmniej do podmiotów ludzkich), akt komunikacji niesie ze sobą niebezpieczeństwo kontaminacji i utracenia własnych, indywidualnych granic.

\section{Immunitas i negatywność indywidualizacji}

Dlatego też wymiarowi communitas zawsze musi towarzyszyć mechanizm immunitas, immunizacji podmiotu od wspólnotowej negatywności. Skoro communitas oznaczała dzielenie się wspólnym munus, ten, który jest immunis otrzymał dispensatio od przymusu wzajemnego obdarowywania. Immunitas należy zatem pojmować, przynajmniej z początku, jako zwolnienie od obowiązku, wyłączenie z przymusu przekazywania munus. ${ }^{19} \mathrm{~W}$ sensie prawnym immunitet jest więc wyłączeniem jednostki z konieczności podporządkowania się powszechnym przepisom prawa, a immunizacja w sensie biologicznym kontroluje i ogranicza konieczną dla organizmu wymianę ze środowiskiem.

Pierwszym wnioskiem z takiego ujęcia problemu jest uznanie reakcyjnego charakteru immunizacji. Jeśli immunitas jest obroną wznoszoną wobec negatywności communitas, „oznacza to, że mechanizm immunizacji zakłada obecność zła, któremu ma za zadanie się przeciwstawić”20. Objawia się w tym momencie cała złożoność dialektyki immunizacji. Relacja między komunizacją a immunizacją nie polega bowiem na wznoszeniu granic przeciwko zagrażającemu nam żywiołowi negatywności. Tak, jak życie wspólnotowe wymaga ekspozycji wnętrza na zewnętrze, tak samo mechanizm tworzenia indywiduum wymaga inkorporacji tego, co negatywne (zagrażającego tożsamości i bytowi podmiotu). „Dialektyczna figura, która się w tym miejscu zarysowuje, polega na wyłączającym włączeniu lub też na wyłączeniu zapośredniczonym poprzez włączenie" 21 . To, co negatywne musi zostać zanegowane, by zachować podmiot przy życiu; jest 
jednak jednocześnie warunkiem skuteczności samego procesu immunizacji. Nie może zostać zatem nigdy zupełnie wyłączone, wyrzucone na zewnątrz, ponieważ jako element systemu odpornościowego (np. antygen dla przeciwciała) współtworzy mechanizm tworzenia jednostkowego (a także wspólnotowego) życia.

Widać w tym momencie, w jaki sposób Esposito jest w stanie podazżyć tropem Haraway i ująć system immunologiczny jako mechanizm produkujący różnicę między ja i nie-ja. Podstawę do takiego rozumienia immunizacji biologicznej dał już w latach osiemdziesiątych czesko-amerykański immunolog Jan Klein, który swojemu podręcznikowi do immunologii nadał podtytuł Nauka o rozróżnianiu ja od nie-ja ${ }^{22}$. Klein podkreślał, że proces immunizacji organizmu należy rozumieć nie tyle jako obronę przed tym, co nim nie jest, co raczej jako proces uznawania, co jest organizmem, a co nim nie jest. Tym samym prawdziwym niebezpieczeństwem dla jego życia jest nawet nie zagrożenie z zewnątrz, lecz jego własny atak przeciwko niemu samemu (choroba autoimmunologiczna).

Relacja między komunizacją i immunizacją jest relacją wzajemnego zakładania i odniesienia. Wspólnota, by istnieć, potrzebuje utworzenia mechanizmów, które ją negują (być immunis oznacza po prostu nie być wspólnym lub też nie mieć żadnego udziału w tym, co wspólne). Jednostka, by się rozwijać (czytaj: by żyć), czyli by pozostać w aktywnej relacji do własnego zewnętrza, musi nieustannie negować to, co neguje ją samą. Owo napięcie wzajemnej negacji między komunizacją i immunizacją w oczach Esposita jest w rzeczywistości kwestią życia i śmierci. Ekstaza wspólnotowego życia, dzielenia się wspólnotowym munus, która dochodziła do głosu w nielicznych momentach nowoczesnej myśli, była jednocześnie zagrożeniem wywłaszczenia i śmierci ${ }^{23}$. Bezpieczeństwo i tożsamość jednostkowego życia (idée fixe nowoczesności) była zawsze reakcją na zagrożenie jego negacji. Niebezpieczeństwo tkwiące w nowoczesnej myśli politycznej polega jednak na tym, że stara się ona sformułować ramy istnienia podmiotowego życia (jednostki i społeczeństwa/narodu/państwa) bez odniesienia do wymiaru communitas:

\begin{abstract}
To, że polityka zawsze w pewnym sensie za swój przedmiot miała ochronę życia nie umniejsza faktu, iż od pewnego momentu, który zbiega się dokładnie z początkami nowoczesności, tego rodzaju wymóg samo-obrony był nie tylko postrzegany jako coś danego, lecz jako problem i strategiczna opcja. Jest przy tym zrozumiałe, że wszelkie cywilizacje obecne i przeszłe musiały zmierzyć się z (i w jakiś sposób je rozwiązać) problemami wynikającymi z potrzeb swojej własnej immunizacji. Jednak dopiero w nowoczesności immunizacja stanowi ich właściwe ufundowanie ${ }^{24}$.
\end{abstract}

\section{Modernitas i paradygmat immunizacji}

Logikę immunizacji oraz jej stopniowe uniezależnianie się od wymiaru wspólnotowego Esposito traktuje jako pojęcie szersze od klasycznych charakterystyk nowoczesności: racjonalizacji u Webera, sekularyzacji u Löwitha oraz legitymizacji u Blumenberga ${ }^{25}$. Odniesienie wymiaru immunizacji do komunizacji umożliwia bowiem śledzenie nowoczesnych dyskursów tworzenia politycznej (indywidualnej i zbiorowej) podmiotowości

\section{W ten sposób dochodzi włoski filozof do określenia nowoczesności jako paradygmatu immunizacji, w którym naczelną zasadą przyświecającą dyskursom filozoficzno-politycznym było zadanie}

conservatio vitae

i diagnozowanie momentu wykluczenia negatywności communitas.

W ten sposób dochodzi włoski filozof do określenia nowoczesności jako paradygmatu immunizacji, w którym naczelną zasadą przyświecającą dyskursom filozoficzno-politycznym było zadanie conservatio vitae ${ }^{26}$. Nie rozstrzyga się w tym miejscu pytania, czy to dyskursy te doprowadziły do typowo nowoczesnych transformacji społecznych (lub przynajmniej niektórych z nich), czy też to radykalne zmiany społeczne wymusiły na myślicielach odpowiednią odpowiedź (jakakolwiek jednoznaczna odpowiedź byłaby zapewne 
błędna). Chodzi raczej o genealogiczną analizę wybranych dyskursów nowoczesności, które za swój cel wzięły ochronę danego i określonego już podmiotu przed niebezpieczeństwami śmierci i nadużycia władzy (przede wszystkim ze strony innych, stanowiących zagrożenie jako jego potencjalni zabójcy). Podmiot stojący w centrum tego paradygmatu immunizacji okazuje się tym samym podmiotem, o którym pisał Heidegger, że za pomocą reprezentacji konstytuuje siebie w sferze pewności ${ }^{27}$. Immunizowany podmiot jest jedynie reprezentacją oddzieloną od ożywiającej wspólnotowe życie negatywności.

Nowoczesny paradygmat immunizacji możemy postarać się wstępnie scharakteryzować za pomocą trzech dyspozytywów ${ }^{28}$ : suwerenności, własności i wolności. Suwerenność, przede wszystkim w teorii Hobbesa, jest odpowiedzią na zagrożenie stanu naturalnego, który charakteryzuje on jako wojnę wszystkich ze wszystkimi. Esposito za motor napędowy jego teorii uważa strach: pierwotny lęk przed śmiercią jest impulsem prowadzącym do konstytucji społeczeństwa opartego na lęku przed państwem-suwerenem ${ }^{29}$. Wzbudzający lęk Lewiatan ma być jednak gwarantem immunizacji jednostek, ochrony przed stanem natury. Napięcie między communitas a immunitas zostaje u Hobbesa sformułowane jako jednoczesne włączenie i wyłączenie negatywności w postaci niebezpieczeństwa śmierci, co prowadzi jednak do neutralizacji wymiaru wspólnotowego. Communitas zostaje wyparte jako groźny stan natury, negatywność w postaci władzy śmierci nadana natomiast suwerenowi jako narzędzie gwarancji bezpieczeństwa. „Suwerenność jest nie-byciem [il non essere] razem przez indywidua, polityczną formą ich desocjalizacji”"

Własność i wolność, odgrywające szczególnie istotną rolę w rozwoju myśli liberalnej, również przyjmują specyficznie immunitarny charakter, okazując się koniec końców dyspozytywami ochrony jednostki. Koncepcja własności, zwłaszcza w sformułowaniu Locke’a, prowadzi do stworzenia pojęcia jednostki związanej przede wszystkim z własnym ciałem, jako że pierwotna relacja własności, będąca podstawą wszystkich innych aktów przywłaszczenia, opiera się na stosunku indywiduum do własnego ciała: „Własność jest przedłużeniem podmiotowej tożsamości - lub też rozszerzeniem podmiotowej tożsamości poza nią samą"31. Jest to swego rodzaju fundamentalna dla pojęcia podmiotowości proteza, która czyni własność (poprzez pracę) częścią podmiotu (a dokładniej mówiąc, częścią ciała podmiotu). Problem polega nie tylko na tym, że tak pomyślana własność staje się problematyczna w momencie wprowadzenia rozróżnienia na własność faktyczną (u Kanta possesio phaenomenon) oraz własność w sensie prawnym (odpowiednio possesio noumenon). Chodzi raczej o to, że logika własności jako podstawa konstrukcji podmiotowości odrywa ją od wszelkiego wymiaru wspólnotowego, zamykając w obszarze zreifikowanej cielesności. Otwiera tym samym drogę do jej postępującego i nieopanowanego uprzedmiotowienia.

W obliczu koncepcji suwerenności i własności, także i nowoczesne pojęcie wolności przyjmuje wyraźnie negatywną charakterystykę. Zostaje koniec końców zredukowane do kwestii bycia panem (suwerenem) samego siebie oraz wolnego dysponowania swoją własnością. Jego immunitarna charakterystyka objawia się w funkcji, jaką wolność ma pełnić: „wolność nie jest tylko obroną przeciwko naruszeniom popełnianym przez innych; jest również podmiotowym prawem, które odpowiada biologiczno-naturalnemu obowiązkowi zachowania samego siebie przy życiu w możliwie najlepszym stanie"32. Ponieważ jako główny gwarant tak rozumianej wolności postrzegano w nowoczesności prawo, wolna jednostka staje się zasadniczo właśnie jego wytworem. Wychodząc od myślenia o podmiocie jako indywiduum, które „nie przechodzi żadnej transformacji ani nie doświadcza wywtaszczenia $w$ doświadczeniu komunizacji”, wolność jako zdolność do samodzielnego sterowania swoimi działaniami (i tym samym jako problem etyczny) zostaje podporządkowana prawu. Komentując Kanta, Esposito pisze:

Prawo jest faktycznie jedyną miarą, podług której można określić, czy dane działanie, lub prościej rzecz biorąc, dana maksyma jest dobra czy zła. Prawo tym samym musi logicznie poprzedzać wolność, ponieważ działanie czy maksyma tego rodzaju swój początek znajdują nigdzie indziej, tylko w prawie ${ }^{33}$. 
Ugruntowanie prawa na relacji intersubiektywności niewiele w tym zakresie zmienia. Wolność (rozumiana jako liberty) okazuje się być całkowicie podporządkowana regulacjom społecznym (przede wszystkim prawu). Immunizacja jednostki, mająca zachować ją jako wolną, prowadzi do tworzenia coraz większej ilości przepisów i ograniczeń, by tę jednostkę jako taką zachować. Nic dziwnego zatem, że jeden z najzagorzalszych zwolenników liberalizmu okazuje się być jednocześnie pomysłodawcą i projektantem panoptykonu ${ }^{34}$.

W interpretacji Esposita dwie, zazwyczaj uznawane za rozłączne, nowoczesne tradycje myśli politycznej, etatyzm oraz liberalizm, zbiegają się w miejscu, w którym na jaw wychodzi zadanie ochrony i bezpieczeństwa (życia). We wszystkich tych teoriach podmiotem (subiectum, poddanym) władzy jest racjonalna jednostka, która używa swej racjonalności, by zagwarantować sobie bezpieczne życie. Na owej koncepcji racjonalności opiera się także idea wolności, spajająca niejako wszystkie nowoczesne projekty społeczne. Okazuje się jednak, że terminy te: wolność, własność (a także równość, a nawet racjonalność) służą (albo inaczej: mogą także posłużyć) podporządkowaniu jednostki (państwu bądź rynkowi). To właśnie ową racjonalność atakował Foucault, kiedy krytykował nowoczesne podporządkowanie podmiotu totalności państwa ${ }^{35}$.

Prawdziwa wartość teorii Esposita polega na tym, że rekonstruując logikę immunizacji jako inkorporację elementu negującego życie w celu własnej ochrony, pokazał, w jaki sposób w koncepcjach immunizacji podmiotu kryje się także największe dla niego zagrożenie. Immunizacja bowiem może łatwo przekształcić się w chorobę immunologiczną (autoimmunizację), w której ten sam mechanizm, które podmiotowość buduje, jest tym, który ją niszczy ${ }^{36}$.

\section{Corpus i biopolityka}

Biopolityka zatem, koekstensywna według Esposita z nowoczesną filozoficzną konstrukcją podmiotowości indywidualnej i podmiotowości zbiorowej, skupiona jest na zadaniu ochrony życia. Aby ochrona ta była możliwa, trzeba wpierw znaleźć odpowiednią jednostkę życia, która może tej ochronie podlegać. Jednostką tą jest ciało, stanowiące pierwotną granicę oddzielającą wnętrze od zewnętrza. Jednak „jeśli ciało jest uprzywilejowanym miejsce rozwoju życia, jest także miejscem, w którym w większym stopniu niż gdziekolwiek indziej natrafiamy na wyzwanie śmierci" ${ }^{37}$, czy to w postaci choroby, ochrony przed chorobą, czy też przyswajania pokarmu. Ciało ufundowane jest na logice immunizacji: „by być ciałem, musi ono zachowywać się przy życiu [...]; [ciało] jest frontem symbolicznego i materialnego oporu życia konfrontującego się ze śmiercią" 38 .

Tym samym ciało sytuuje się w centrum polityki immunizacji - zachowanie go przy życiu wymaga nieustannej konfrontacji z wymiarem śmierci, negatywności. Choć ciało zbudowane jest na pierwotnej granicy między wnętrzem i zewnętrzem, granica ta jest reprodukowana we wnętrzu samego ciała. Antyciała systemu immunologicznego, by funkcjonować, potrzebują wejść $\mathrm{w}$ interakcję $\mathrm{z}$ antygenami. Te muszą zatem wniknąć do wnętrza ciała. Proces immunizacji, nieustannie odróżniający ja-ciała od nie-ja-ciała, ciało od jego

\section{Ciało sytuuje się w centrum polityki immunizacji - zachowanie go przy życiu wymaga nieustannej konfrontacji z wymiarem śmierci, negatywności.}

zewnętrza, działa w jego wnętrzu, komplikując radykalnie samą logikę granicy między wnętrzem i zewnętrzem. Granica ta jest rekonstruowana jedynie pod warunkiem naruszenia istniejącej już granicy, poprzez inkorporację negatywności.

Ponieważ ciało jest przedmiotem polityki immunizacji, Esposito określa nowoczesność, z racji postępującego procesu ucieleśniania [incorporazione] podmiotowości, tak zbiorowej, jak i indywidualnej, jako paradygmat immunizacji. Zarówno Hobbes, jak i Locke pojmowali podmiot jako ciało: ciało suwerena, przedstawione na siedemnastowiecznych rycinach jako 
makabryczny potwór złożony z pojedynczych ciał poddanych oraz ciało podmiotu rynku, którego relacja do własnego ciała konstytuuje podstawę prawa własności. Wolność to suwerenne sprawowanie władzy nad własnym ciałem, które oparte jest na prawie do nienaruszalności ciała ${ }^{39}$.

Ciało konstytuuje także właściwy przedmiot biopolityki. Nie tylko bowiem jest obiektem mechanizmów dyscyplinarnych - biologiczny wymiar kooperacji między ciałami zostanie w dziewiętnestym wieku, według Foucaulta, objęty pojęciem populacji. Oba te aspekty kontroli ciała są składowymi biopolityki jako władzy nad życiem: „Organizacja władzy nad życiem skupia się na dwóch biegunach: dyscypliny ciała i regulacji ludnościowych” ${ }^{40}$. Choć Foucault podkreślał różnicę między technikami dyscypliny, skupionymi na pojedynczym, zindywidualizowanym ciele, oraz technikami urządzania, które koncentrowały się na populacji, perspektywa proponowana przez Esposita jest w stanie oba te wymiary połączyć. Regulacje władzy urządzającej oparte są bowiem na statystykach wydarzeń i procesów przynależących do konstytutywnego dla składających się na daną populację ciał procesu immunizacji, takich jak częstotliwość zachorowań i zgonów.

Ciało suwerennego narodu u Hobbesa oraz ciało populacji u Foucaulta z pewnością się różnią, co nie zmienia jednak faktu, że w jednym i drugim przypadku mamy do czynienia z ciałem. Pojęcie populacji było możliwe tylko o tyle, o ile rodzące się nauki statystyczne, społeczne i biologiczne były w stanie skonstruować wspólny przedmiot swoich dyskursów, tym samym konstytuując populację jako charakteryzujący się określonymi regularnościami byt biologiczno-społeczny (a nie zbiór jednostek w sensie prawnym). Populacja pozwala myśleć człowieka w odniesieniu do jego wymiaru gatunkowego, do postrzegania jednostki jako egzemplarza konkretnego gatunku. Tym samym zaś „jedynym elementem jednoczącym wszystkie jednostki w jednym gatunku jest posiadanie ciała” ${ }^{\circledR 1}$. Różnica polega nie tyle na „niecielesnym” charakterze którejś z tych teorii filozoficznych, lecz raczej na obecnej w nich wizji relacji między ciałami.

Aby pokazać różnicę między ciałem Lewiatana a ciałem populacji (czy raczej ciałami populacji), można odwołać się do politycznych pism dziewiętnastowiecznego niemieckiego lekarza i polityka, Rudolfa Virchowa. Był on twórcą teorii patologii komórkowej (swego czasu niezwykle wpływowej), jednym z pierwszych teoretyków medycyny społecznej (którą postrzegał jako naukę) ${ }^{42}$, członkiem partii liberalnej, wielkim przeciwnikiem Bismarcka oraz propagatorem nowych rozwiązań w dziedzinie higieny, a także projektantem berlińskiego systemu kanalizacyjnego. Czy można sobie wyobrazić postać historyczną lepiej pasującą (może poza Benthamem) do opisywanych przez Foucaulta tendencji przeplatania się rozwoju liberalizmu oraz biopolityki?

To jednak nie tylko pewien wspólny wymiar łączący obszary działalności Virchowa (sprowadzenie wszelkich pytań społecznych i politycznych do, w gruncie rzeczy, problemów medycznych), lecz przede wszystkim dokonana przez niego teoretyzacja tego wymiaru, oparta o teorię patologii komórkowej, jest w tym miejscu najważniejsza. Rozwijana przez Virchowa nauka o tkankach (podstawa jego patologii komórkowej) stwierdzała, że zdrowie (a dokładniej: cechująca życie jedność) jest efektem współdziałania każdego elementu składającego się na daną tkankę czy organizm ${ }^{43}$. Podobnie zatem „zdrowie” narodu (Virchow mówił raczej o społeczeństwie lub państwie) zależne jest od zdrowia każdej jednostki „składającej” się na daną grupę ${ }^{44}$. Przedmiotem zainteresowania medycyny społecznej jest zatem każde indywidualne ciało, którego zdrowie bądź choroba oznacza, odpowiednio, pozytywny bądź negatywny wpływ na zdrowie całego społeczeństwa. Każde ciało się liczy, bowiem ciało społeczne „nie jest ani totalnym królestwem, ani też zjednoczonym w jednej, własnej woli powszechnej narodem, lecz raczej wspólnotą ukonstytuowaną na różnicach wszystkich swoich członków" ${ }^{4}$.

Zestawienie Virchowa z Hobbesem prowadzi do oczywistych wniosków. Ciało Lewiatana, podobnie jak Zellenstaat, państwo komórkowe Virchowa, zbudowane jest z ciał składających się na niego ludzi. Jednak ciało suwerenne ma wyraźnie wyróżniony organ - głowę której przetrwanie stawiane jest ponad wszystkie inne elementy korporalne: pojedynczy osobnik liczy się tylko o tyle, o ile wzmacnia władzę głowy. Głowa zatem może 
skazać na śmierć każdego, kto jej zagraża. Ciało Lewiatana, mówiąc inaczej, może jedynie powstać i się rozpaść, trudno mówić w jego przypadku o stopniach zdrowia. Negatywność wkracza w nie jedynie jako zagrożenie (stan natury), które musi zostać natychmiast wyeliminowane, inaczej doprowadzi do rozpadu całości. Dlatego też suweren jako jedyny pozostaje w odniesieniu do stanu naturalnego, gdyż to jego egzystencja zostaje zagrożona w momencie wkroczenia do suwerennego ciała negatywności. Skazując na śmierć tego, kto wykroczył przeciwko jego prawu, jednym słowem czy jednym gestem odróżnia on to, co (jeszcze) jest (jego) ciałem od tego, co (już) nim nie jest.

Ciało populacji, państwa komórkowego, które wyznacza horyzont biopolityki, jest obszarem ciągłej obecności negatywności. Każda śmierć i każda choroba, stanowiące zagrożenie dla życia, współtworzą napięcia w egzystencji tego specyficznego „ciała bez organów”, jako że składają się na jego ogólny stan zdrowotny. Ciało biopolityczne ani nie ma swojego ontologicznego początku (wywodzi się zawsze z chaosu wojny), ani też nie grozi mu zupełne unicestwienie (w przeciwieństwie do degeneracji). Proces fundowania dystynkcji ja-ciała od nie-ja-ciała zachodzi permanentnie we wnętrzu każdej komórki społecznej. Bowiem zarówno ciało suwerenne, jak i społeczne ciało biopolityczne wytwarzają w swej cielesności (a raczej są wytwarzane przez) własny system immunologiczny.

\section{Tanatopolityka i wyjście poza paradygmat immunizacji}

Oparcie, czy raczej reinterpretacja Foucaultowskiej teorii biopolityki na pojęciu immunizacji jest w stanie, według Esposita, wytłumaczyć tkwiący w późnych pismach francuskiego filozofa paradoks, który sam Esposito nazwał „enigmą biopolityki”. Mówiąc krótko, owa „zagadka” polega na jednoczesnej obecności w okresie, w którym Foucault lokuje rozwój biowładzy, zarówno instytucji i dyskursów skupionych wokół troski o życie, chroniących je, dbających o jego rozwój, jak i regulowanych państwowo procesów uśmiercania całych populacji, których kulminacją, przynajmniej w kontekście Europy, był nazizm. Albo formułując problem w jednym pytaniu: „Jak to było możliwe, że władza życia była sprawowana przeciwko niemu samemu?"46

Do podobnego sformułowania tego zagadkowego charakteru polityki europejskiej dziewiętnastego i dwudziestego wieku doszedł sam Foucault w swoich wykładach z roku 1976, poświęconych dyskursom wojny. Przeciwstawił on w nich (w duchu Woli wiedzy) władzę suwerenną oraz biopolitykę jako, z jednej strony, „prawo skazywania na śmierć i zezwalania na życie”, a z drugiej władzę „»skazywania«» na życie i »zezwalania«» na śmierć" ${ }^{47}$. Zarazem jednak pojawia się w ramach tych wykładów logika jednoczesnej obecności obu rodzajów władzy. Wpierw Foucault podkreśla współistnienie władzy suwerennej oraz pierwszej, jeśli można tak to ująć, „składowej” władzy nad życiem:

Jest to władza [dyscyplinarna - przyp. MR] wymykająca się opisowi, nie dająca się uzasadnić w terminach teorii suwerenności, radykalnie heterogeniczna i która normalnie powinna pociągnąć za sobą zanik tej wielkiej konstrukcji prawnej, jaką była teoria suwerena. W rzeczywistości jednak teoria ta nie tylko nadal istniała jako, by użyć tego określenia, ideologia prawa, ale też organizowała kodeksy prawne, jakie, poczynając od kodeksów napoleońskich, zaczęły powstawać w Europie w ciaggu XIX wieku ${ }^{48}$.

Od samego stwierdzenia obecności konstrukcji prawnych opierających się na pojęciu suwerenności Foucault przechodzi jednak, w ostatnim wykładzie w tym cyklu, do trudnego pytania odnoszącego się do koncepcji biowładzy: „Jak taka władza może zabijać, jeżeli jest prawdą, że z istoty chodzi jej o poprawę życia, o jego przedłużenie, o zwielokrotnienie jego szans, o zapobieganie wypadkom albo i kompensowanie braków?” ${ }^{49}$. Pytanie to pada w momencie, w którym Foucault podejmuje problem rasizmu oraz nazizmu jako fenomenów niedających się tak łatwo wpasować w koncepcję opartą na różnicy między suwerennością i biowładzą. Odpowiedzią Foucaulta jest, jak powszechnie wiadomo, jego genealogia dyskursów o wojnie i teza o dokonującej się w dziewiętnastym wieku reinterpretacji tych dyskursów 
w biologicznym rejestrze pojęciowym (już nie wojna między rodami, narodami itd., ale między rasami).

Esposito uważa jednak, że można tę współobecność władzy masowych mordów i władzy dbającej o życie sprowadzić do wspólnego pnia, którym jest właśnie paradygmat immunizacji. Władza suwerenna oraz biowładza (rozumiane nie diachronicznie, lecz synchronicznie) są po prostu dwiema reakcjami immunizacji: ta druga stara się zachować ciało przy życiu, ta pierwsza usuwa z niego zagrożenia dla jego egzystencji (zgodnie z zasadą, że proces immunizacyjnej dystynkcji przebiega wewnątrz ciała). Różnica między tym, co Foucault nazywał władzą suwerenną i biowładzą, polega na różnej relacji pojedynczych ciał do ciała społecznego („,body politic”, by użyć tu tego angielskiego określenia): przedmiotem ochrony u Hobbesa było ciało suwerena, przedmiotem ochrony u Virchowa pojedyncze ciała. Inna jest też zatem w obu przypadkach logika funkcjonowania negatywności życia:

Należałoby powiedzieć, że jeśli antyczne prawo suwerenności strzeże życia z punktu widzenia dystrybucji śmierci, to nowy porządek biopolityczny nadał także śmierci funkcję w procesie koniecznej reprodukcji życia ${ }^{50}$.

Ta obecność immunizującej śmierci w strategiach nowoczesnej biopolityki ukazuje się w pełni w przypadku nazizmu. Połączył on bowiem z jednej strony prawno-suwerenny aspekt władzy nad życiem, władzy śmierci, oraz specyficzną dla biopolityki logikę relacji między ciałem społecznym i ciałami jednostkowymi: każda chora jednostka jest jednocześnie zagrożeniem dla zdrowia wszystkich innych jednostek, całego ciała narodu. Tym samym otwarta zostaje droga do prawnej kodyfikacji biologicznej teorii o degeneracji.

W swojej książce poświęconej biopolityce Esposito tropi dyskursywne korzenie nazistowskich koncepcji degeneracji i możliwej regeneracji życia narodu (Volk), zarówno w dziewiętnastowiecznych teoriach degeneracji, opartych luźno na naukach Darwina, jak i popularnych na początku dwudziestego wieku pomysłach eugenicznych. Swoje genealogiczne badania podsumowuje jednak pewną próbą synchronicznego ujęcia bio- polityki nazizmu. Jego totalitarne podejście do ochrony życia ujął włoski filozof w trzech dyspozytywach, z których każdy prezentuje pewną wykrzywioną hiperbolizację niektórych z podstawowych zasad nowoczesnego porząaku politycznego.

Pierwszym dyspozytywem jest „absolutna normatywizacja życia”, w której spotykają się dwa wymiary immunizacji: biologiczny i prawny ${ }^{51}$. Nazizm starał się w sposób prawny determinować praktycznie każdy przejaw biologicznie rozumianego życia. Jako drugi Esposito wymienia dyspozytyw „podwójnego zamknięcia ciała”, który rozumie jako sprowadzenie wymiaru egzystencji każdej jednostki do jej ciała ${ }^{52}$. Trzecim dyspozytywem jest „uprzednie stłumienie narodzin”. Szczytem normatywnej kontroli zredukowanych do swoich ciał jednostek jest kontrola ich procesu rozmnażania się ${ }^{53}$. Forma artykułu uniemożliwia pełną interpretację sformułowanej przez Esposita listy dyspozytywów w kontekście dialektyki komunizacji i immunizacji. Wystarczy jednak podkreślić, że dyspozytywy te są skrajną wersją adaptowanego przez nowoczesną politykę paradygmatu immunizacji negatywności, której celem była zawsze ochrona podmiotu, z góry ontologicznie oraz politycznie określonego jako ciato. Połączenie wymiaru biologicznego i prawnego, reifikacja cielesności jednostki, suwerenne sprawowanie kontroli nad procesami biologicznymi, wykluczenie tych zachowań, które znoszą granicę indywidualnej cielesności (jak np. poczęcie i ciąża) - są to jedne z obszarów, które łączą nazizm z immunitarnym wymiarem nowoczesnej polityki.

Kulminacją nazizmu była prawdziwa polityka śmierci, tanatopolityka, która swój najradykalniejszy wyraz znalazła, z jednej strony, w komorach gazowych Auschwitz, a z drugiej w ostatnim rozkazie Hitlera, wydanym już w jego berlińskim bunkrze, rozkazującym całemu narodowi niemieckiemu masowe samobójstwo. Obie te twarze nazizmu łączą się w zadaniu ochrony niemieckiej rasy przed degeneracją w kontakcie z chorymi osobnikami/ciałami, a potem w zniszczeniu samego niemieckiego ciała, które okazało się za słabe, by przeżyć. Trudno do końca, przynajmniej trzymając się kategorii Foucaulta, zadecydować, czy te tanatopolityczne oblicza nazizmu mają charakter 


\section{Rozwiązaniem „enigmy biopolityki” jest immunizacja,} która poprzez inkorporację negatywności ma za zadanie

raczej biowładzy, czy władzy suwerennej, zwłaszcza jeśli weźmie się jeszcze pod uwagę analizy Agambena, porównujące prawną konstrukcję obozu z suwerenną koncepprzede wszystkim rekonstruować granice i tożsamość podmiotu w kontakcie z jego zewnętrzem, utrzymując go jednocześnie przy życiu cją arcanum imperii ${ }^{54}$. Celem jednak, który przyświecał Espositowi przy tworzeniu listy tanatopolitycznych dyspozytywów polityki nazistowskiej, było podkreślenie faktu, że „W reżimie biopolitycznym suwerenne prawo jest dyspozycją nie tyle do zadawania śmierci, co do uprzedniego anulowania życia" ${ }^{5}$.

Aby podsumować zarówno genealogiczne analizy biopolityki u Esposita, jak i jego próbę systematycznego ujęcia problematyki biopolitycznej, można stwierdzić, że rozwiązaniem „enigmy biopolityki” jest immunizacja, która poprzez inkorporację negatywności ma za zadanie przede wszystkim rekonstruować granice i tożsamość podmiotu w kontakcie z jego zewnętrzem, utrzymując go jednocześnie przy życiu. Moment przymusowego kontaktu z negatywnością może być jednak również przekształcony w koncepcję ochrony jednostki: nie tyle aktywnego (a raczej reaktywnego) procesu dystynkcji ja od nie-ja, co statycznego konceptu ochrony ontologiczo-polityczno-biologicznie zdefiniowanej podmiotowości. Punktem szczytowym tanatopolityki nazizmu, której jednym z efektów były masowe ludobójstwa, dokonane zarówno na ciele niemieckiego narodu, jak i na całych „podrzędnych” grupach społecznych, było doprowadzenie do skrajności owej kon-

cepcji ochrony, którą Esposito nazywa paradygmatem nowoczesności.

Pozostaje zatem otwarte pytanie, jak można pomyśleć biopolitykę opartą na innym rodzaju immunizacji. Projekty takiej „polityki życia”, czy też „,biopolityki afirmatywnej" Esposito rozwinął w ostatnich rozdziałach swoich książek Immunitas oraz Bios. Zwłaszcza koncepcja zarysowana w tej drugiej pozycji prezentuje się interesująco, jako że polega na oparciu idei biopolityki afirmatywnej na swego rodzaju przechwyceniu i przekształceniu trzech tanatopolitycznych dyspozytywów nazizmu. W odniesieniu do nich włoski filozof mówi o (1) „normie życia”, (2) ciele w jego materialnym, biologicznym sensie („mięsie” [flesh]) oraz (3) narodzinach jako o teorematach, na których można zbudować koncepcję polityki wykraczającą poza ograniczający, a nawet śmiercionośny paradygmat immunizacji. Polityka musiałaby zrezygnować z klasycznego ograniczenia podmiotu, tak indywidualnego, jak i zbiorowego, do jego ciała, dopuszczając jako podmiotowości polityczne różnego rodzaju hybrydyzacje, nowe formy kolektywnego współistnienia itp. ${ }^{56}$ Mówiąc inaczej, nowe formy wspólnoty. 
1 O AIDS pisały m.in. S. Sontag, Choroba jako metafora: AIDS i jego metafory, tłum. J. Anders, Warszawa 1999 (tekst poświęcony AIDS ukazał się w roku 1988) oraz P. Treichler, AIDS, Homophobia, and Biomedical Discourse: an Epidemic of Signification, "October" 1987, Vol. 43; zob. tejże, How to Have Theory in Epidemic: Cultural Chronicles of AIDS, Duke 1999.

2 D. Haraway, The Biopolitics of Postmodern Bodies: Determination of Self in Immune System Discourse, "Differences” 1989, No. 1. Tekst ten ukazał się następnie w książce Haraway Simians, Cyborgs and Women: the Reinvention of Nature, New York 1991.

3 Tamże, s. 204.

4 G. Borradori, Filozofia w czasach terroru, tłum. A. Karalus, M. Kilanowski, B. Orlewski, Warszawa 2008. Po polsku ukazał się także tekst Derridy, w którym analizował on pojęcie autoimmunizacji w kontekście politycznym i teologicznym, zob. J. Derrida, Wiara i wiedza: dwa źródta religii w obrębie samego rozumu, tłum. M. Kowalska, [w:] J. Derrida, G. Vattimo [i in.], Religia, Warszawa 1999. Analizy relacji między pojęciem autoimmunizacji u Derridy i immunizacji u Esposita dokonuje Timothy Campbell, zob. T. Campbell, Bios, Immunity, Life: the Thought of Roberto Esposito, [w:] R. Esposito, Bios: Biopolitics and Philosophy, tłum. T. Campbell, Minneapolis 2008, s. XIII-XIX.

5 R. Esposito, Immunitas: protezione e negazione della vita, Torino 2002

6 W książce tej Esposito porusza zagadnienia teorii przemocy i prawa, teologii politycznej, antropologii filozoficznej, biopolityki oraz „biofilozofii” procesu immunologicznego.

7 Tegoż, Communitas: the Origin and Destiny of Community, trans. T. Campbell, Stanford 2010.

8 Tegoż, Communitas..., s. 3-6.

9 Tamże, s. 4 (Esposito przywołuje w tym miejscu wyrażenie Ulpiana Domicjusza).

$10 \mathrm{Na}$ temat związku między konstytucją wspólnoty oraz relacją wymiany darów zob. przede wszystkim studia Benveniste'a oraz wcześniejsze badania Maussa: É. Benveniste, Indo-European Language and Society, tłum. E. Palmer, Miami 1974, s. 53-104; M. Mauss, The General Theory of Magic, tłum. R. Brain, London 1972, s. 108-121, cyt. za R.Esposito, Communitas..

11 Tamże, s. 5.

12 Tamże, s. 5.

13 We współczesnych dyskursach filozoficznych, krytycznych w odniesieniu do tego, co wspólne czy też dobra wspólnego (the common) lub dóbr wspólnych (the commons) niemożliwość przywłaszczenia jest jednym z najważniej- szych kryteriów odróżniania tego, co wspólne, od publicznego i prywatnego, zob. M.Hardt, A. Negri, Rzecz-pospolita. Poza wtasność prywatna i dobro publiczne, tłum. Praktyka Teoretyczna, Kraków 2011 (w przygotowaniu). Hardt i Negri rozumieją jednak to, co wspólne, jako (nie) materialne dobra, w rodzaju zasobów natury czy też produktów pracy biopolitycznej (idei, emocji, kodów, struktur upodmiotowienia). Materialne czy nie, instancje dobra wspólnego pozostają u nich (jako marksistów i deleuzjanistów) czymś pozytywnym. Esposito skupia się jednak na negatywnym wymiarze doświadczenia i pojęcia wspólnoty, o czym dalej w tekście. Wyzwanie dla nowych teorii polityki emancypacyjnej powinna stanowić próba nie tyle pogodzenia, co konstruktywnej konfrontacji obu tych perspektyw.

14 Esposito kontynuuje tutaj linię myślenia o wspólnocie, którą w swojej książce Rozdzielona wspólnota rozwinął Jean-Luc Nancy, zob. J.-L. Nancy, Rozdzielona wspólnota, tłum. M. Gusin, T. Załuski, Wrocław 2010. Esposito jest poza tym autorem tekstów poświęoconych filozofii Nancy'ego, napisał m.in. wprowadzenia do włoskich wydań L'Expérience de la liberté oraz Etre singulier pluriel.

15 R. Esposito, Communitas..., s. 7.

16 J.-L. Nancy The Restlessness of the Negative, thum. J.Smith, S. Miller, Minneapolis-London 2002.

17 G.Agamben, Wspólnota, która nadchodzi, tłum. S. Królak, Warszawa 2008.

18 Zob. J.Derrida, Politics of Friendship, tłum. G. Collins, London-New York 1997.

19 R. Esposito, Immunitas..., s. 8.

20 Tamże, s. 10.

21 Tamże, s. 10.

22 J.Klein, Immunology: the Science of Self-Nonself Discrimination, New York 1982.

23 Nic dziwnego zatem, że najważniejsze konteksty w dyskusji nad pojęciem wspólnoty tworzyły myśl Heideggera i Bataille'a. Niemiecki fenomenolog w zasadzie od samego początku rozważał problem „nicestwienia” bycia w relacji bycia-ku-śmierci, który koniec końców doprowadził go do połączenia pytania o śmierć z myśleniem języka, zob. M.Heidegger, $O$ istocie języka, [w:] tegoż, $W$ drodze do języka, tłum. J.Mizera, Warszawa 2007, zwłaszcza s. 195-196. Myśl czy raczej pisarstwo Bataille'a naznaczone jest z drugiej strony napięciem między wspólnotowym wymiarem „eksperymentów" z Collège de Sociologie oraz grupą Acéphale, a samotnym poszukiwaniem negatywności „doświadczenia wewnętrznego", zob. G. Bataille, Doświadczenie wewnętrzne, tłum. O.Hedemann, Warszawa 1998 
24 R. Esposito, Bios..., s. 54-55.

25 Tamże, s. 51.

26 Tamże, s. 56.

27 Zob. M. Heidegger, Czas światoobrazu, tłum. K. Wolicki, [w:] tegoż, Drogi lasu, Warszawa 1997, s. 79.

28 Pojęcie „dyspozytywu” czy też „urządzenia” jest swego rodzaju pojęciem-wytrychem różnych teorii biopolityki. Występuje praktycznie u wszystkich autorów zajmujących się tą problematyką, u każdego przybiera jednak inną postać. Aby krótko scharakteryzować dyspozytyw u Esposita, można by spróbować podać pewną wspólną cechę każdego pojęcia dyspozytywu oraz charakterystyczną dla idiomu włoskiego filozofa differentia specifica. Dispositif tkwi niejako w rdzeniu każdej koncepcji biopolityki, odnosząc się do analizowanego w niej procesu konstrukcji podmiotowości w oparciu o te stosunki sił, które akurat daną koncepcję interesują (regulacja produkcji i reprodukcji społecznej u Hardta i Negriego, ugruntowanie porządku społecznego poprzez stan wyjątkowy u Agambena, normalizacja dyskursywno-instytucjonalna u Foucaulta itd.). U Esposita główną rolę w tworzeniu podmiotowości odkrywa mechanizm immunizacji, a obszarem jego zainteresowań są przede wszystkim dyskursy (i to analizowane nie archeologicznie, lecz pod kątem swojej treści, ewentualnie wypartej treści). Dyspozytyw będzie się zatem odnosić w jego teorii do filozoficznych, prawnych i medycznych teorii, mających za swój przedmiot pojęcie podmiotu w relacji do jego ciała, zewnętrza tego ciała oraz grożących mu niebezpieczeństw, czyli - w odniesieniu do dialektyki komunizacji i immunizacji.

29 R. Esposito, Communitas..., s. 24.

30 Tegoż, Bios..., s. 61.

31 Tamże, s. 67.

32 Tamże, s. 73.

33 Tegoż, Communitas..., s. 69.

34 Chodzi oczywiście o Jeremy'ego Benthama, który swoją ideę „domu inspekcji” wyłożył w książce wydanej w 1785 roku, zob. J. Bentham, The Panopticon Writings, red. M. Bozovic, London 1995, s. 29-95. Analiza nowoczesnego dyspozytywu wolności jest odpowiedzą Esposita na podejmowany przez Foucaulta problem liberalizmu, który jednocześnie produkuje wolność (obszary wolności) i zestawy ograniczeń, norm, zobowiązań itd., które tę wolność ograniczają, zob. R. Esposito, Bios..., s. 75.

35 M. Foucault, Technologies of the Self: a Seminar with Michel Foucault, red. L. H. Martin, Massachusetts 1988, s. 152.
36 Ta logika immunizacji przywodzi oczywiści na myśl Derridy analizy „farmakonu”, lekarstwa, które jest jednocześnie trucizną, zob. J. Derrida, Farmakon, tłum. K. Matuszewski, [w:] tegoż, Pismo filozofii, Kraków 1993, s. 43-69. Esposito podejmuje zagadnienie „zła, które jest jednocześnie swoim własnym lekarstwem" od strony problematyki biopolitycznej w Immunitas, zob. R. Esporito, Immunitas..., s. 145-152 (cytat na stronie 152).

37 Tamże, s. 135.

38 Tamże.

39 Zob. Agambena genealogię centralnej pozycji ciała w obszarze średniowiecznej i nowoczesnej terminologii polityczno-prawniczej oraz w dyskursie nowoczesnej myśli politycznej, której korzenie sięgać mają Wielkiej Karty Swobód z roku 1215 i zawartej w niej formuly habeas corpus, G. Agamben, Homo sacer: suwerenna wtadza i nagie życie, tłum. M. Salwa, Warszawa 2008, s. 168-172.

40 M. Foucault, Wola wiedzy, tłum. B. Banasiak, K. Matuszewski, [w:] tegoż, Historia seksualności, wyd. 2, Gdańsk 2010, s. 96.

41 R.Esposito, Immunitas..., s. 163.

42 W Niemczech znana jest maksyma Virchowa: „Medycyna jest nauką społeczną, a polityka niczym więcej niż medycyną w większym wymiarze [Medizin im Großen]".

43 Zob. R. Virchow, Die Cellularpathologie in ihrer Begründung auf physiologische und pathologische Gewebelehre dargestellt, Berlin 1858

44 Zob. ważny w kontekście rozwijanych na początku dwudziestego wieku teorii państwa organizmu (Kjèllen, von Uexkühl, Hertwig) esej Virchowa Alter und neuer Vitalismus, "Archiv für Pathologische Anatomie und Physiologie und für Klinische Medizin” 1856, Vol. 9.

45 R.Esposito, Immunitas..., s. 159.

46 Tegoż, Bios..., s. 39.

47 M. Foucault, Trzeba bronić spoteczeństwa: wyktady $w$ Collège de France, 1976, tłum. M. Kowalska, Warszawa 1998 , s. 238.

48 Tamże, s. 45

49 Tamże, s. 251.

50 R.Esposito, Immunitas..., s. 162.

51 Tegoż, Bios..., s. 138.

52 Tamże, s. 141.

53 Tamże, s 143.

54 G. Agamben, Co zostaje z Auschwitz: archiwum i swiadek, tłum. S. Królak, Warszawa 2008.

55 R.Esposito, Bios..., s. 145.

56 Zob. tamże, s. 157-194. 
Author: Mikołaj Ratajczak

Title: Beyond the Immunization Paradigm: Biopolitics in the Philosophical Project of Roberto Esposito

Summary: The aim of the text is to reconstruct those aspects of Roberto Esposito's philosophy that build the core of his theory. The reconstruction focuses on the concepts of communization, immunization, modernity and biopolitics and tries to explicate the relationship between these terms. The element that binds communization and immunization is negativity, that at the same time makes the common life possible and presents the biggest threat to community. Because the dialectics between community and immunity touches the relation between life and death, the problem of community involves the question of biopolitics.

Keywords: : esposito - Foucault - Agamben - Nancy - Hobbes - Virchow - biopolitics - community immunization - body - modernity - immune system
Mikołaj Ratajczak - absolwent filozofii i student germanistyki w ramach MISH UAM, interesuje się współczesną filozofią kontynentalną, historią filozofii niemieckiej oraz teoriami biopolityki. 